\title{
SOSIO ANTROPOLOGI BUDAYA MAKANAN TERHADAP GIZI DAN KESEHATAN
}

Andi Wulan Purnamasari.A*)

(70200121101)

Program Studi Kesehatan Masyarakat

Fakultas Kedokteran dan Ilmu Kesehatan

Universitas Islam Negeri Alauddin Makassar

Article Info

Keywords:

Sosio culture

Trust

Anthropological literature

Health and nutrition

Food ethics

\section{Kata Kunci:}

Sosial budaya

Kepercayaan

Literatur antropologi

Kesehatan dan gizi

Etika makanan

\section{A b s t r a k}

Pada artikel ini membahas tentang pola budaya, system budaya, masalah yang terjadi, solusi dari masalah tersebut dan antropologi budaya makanan terhadap gizi dan kesehatan serta dimensi etis (etika makanan/food ethics) terhadap pola perilaku/budaya makan yang muncul dalam kehidupan sehari-hari. Pola makan seseorang ternyata dibentuk dari latar belakang budaya yang dimilikinya dengan berbagai perubahan sosial-budaya yang terjadi.

\section{PENDAHULUAN}

Indonesia terkenal dengan berbagai suku dan budayanya, di Provinsi Sulawesi Selatan terdapat empat suku besar yaitu Toraja, Mandar, Makassar, dan Bugis. Suku Toraja didominasi oleh masyarakat Kristen dengan menganut kepercayaan Aluk Todolo. Sedangkan suku Makassar dan Bugis mayoritas beragama Islam dan di antaranya Bulukumba. Factor keyakinan dan agama tentunya akan berdampak pada pemikiran dan rangkaian pola perilaku yang berbeda. Hal ini juga akan mempengaruhi individu dan masyarakat dalam menjaga kesehatannya. Budaya perilaku kesehatan yang ada di masyarakat beragam dan melekat dalam kehidupan sosial. Sehingga upaya yang harus dilakukan untuk mengubah budaya ini adalah dengan mempelajari budayanya dan menciptakan budaya yang inovatif sesuai dengan pola, norma, dan benda yang dibuat oleh manusia. Budaya dan perilaku tidak hanya menjadi penghambat dan tantangan bagi kesehatan, tetapi juga dapat menjadi factor pendukung, adanya sebuah penelitian menunjukkan bahwa budaya tradisional masyarakat merupakan budaya yang diturunkan secara turun temurun.

Kemudian mengenai pola makan, secara umum dipengaruhi oleh factor lingkungan dan kebudayaan. Kebudayaan dan 
lingkungan sekitar menuntun orang dalam berperilaku dan memenuhi kebutuhan dasar biologisnya, termasuk kebutuhan terhadap pangan. (Satrianegara dkk., 2021)

\section{Pola Budaya Terhadap Makanan}

Kebudayaan adalah seluruh system gagasan dan ras, tindakan serta karya yang dihasilkan manusia dalam kehidupan bermasyarakatyang dijadikan miliknya dengan belajar. Selanjutnya dikatakan juga bahwa wujud dari budaya atau kebudayaan dapat berupa benda-benda fisik, sistim tingkah laku dan tindakan yang terpola/sistim sosial, sistim gagasan atau adat-istiadat serta kepribadian atau nilainilai budaya.

Dengan demikian pengaruh budaya terhadap pangan atau makanan sangat tergantung kepada sistim sosial kemasyarakatan dan merupakan hak asasi yang paling dasar, maka pangan/makanan harus berada di dalam kendali kebudayaan itu sendiri. Beberapa pengaruh pola budaya terhadap pangan/makanan adalah: Adanya bermacam jenis menu makanan dari setiap komunitas etnis masyarakat dalam mengolah suatu jenis hidangan makanan karena perbedaan bahan dasar/adonan dalam proses pembuatan. Contoh orang Sulawesi menu makanan beragam yakni berasal dari beras, jagung, dan sagu; orang Jawa ada jenis menu makanan berasal dari kedele; orang Timor jenis menu makanan lebih banyak berasal dari jagung dan orang Ambon jenis menu makanan berasal dari sagu.

Adanya perbedaan pola makan/konsumsi /makanan pokok dari setiap suku/etnis; contoh : orang Timor pola makan lebih kepada jagung dan orang Jawa lebih kepada beras. Adanya perbedaan cita rasa, aroma, warna dan bentuk fisik makanan dari setiap Suku-etnis; contoh : makanan orang Padang cita rasanya pedis, dan orang Jawa makanannya manis. Adanya bermacam jenis nama dari makanan tersebut atau makanan khas berbeda untuk setiap daerah; contohnya : soto Makassar berasal dari daerah Makassar-Sulawesi Selatan, dan jagung "Bose" dari daerah Timor-Nusa Tenggara Timur.

\section{Sistem Budaya Terhadap Makanan}

Berbagai system budaya memberikan peranan dan nilai yang berbeda-beda terhadap makanan, misalnya bahan-bahan makanan tertentu oleh suatu budaya masyarakat dapat dianggap tabu atau bersifat pantangan untuk dikonsumsi karena alasan sacral tertentu atau system budaya yang terkait didalamnya. Di samping itu ada jenis makanan tertentu yang di nilai dari segi ekonomi maupun sosial sangat tinggi eksistensinya tetapi karena mempunyai peranan yang penting dalam hidangan makanan pada sesuatu perayaan yang berkaitan dengan kepercayaaan masyarakat tertentu maka hidangan makanan tidak diperbolehkan untuk dikonsumsinya bagi golongan masyarakat tertentu.

Anggapan lain yang muncul dari sitem budaya seperti dalam mengkonsumsi hidangan makanan di dalam keluarga, sebagai contoh pada system budaya masyarakat di Timor yaitu apabila dihidangkan makanan daging ayam, maka sang ayah akan mendapat bagian paha atau dada sedangkan sang ibu dan anak-anak akan mendapat bagian sayap atau lainnya.

Hal ini menurut (Suhardjo, 1996) dapat menimbulkan distribusi konsumsi pangan yang tidak baik atau Maldistribution diantara keluarga apalagi pengetahuan gizi belum dipahami oleh keluarga. Adapun kasus lain yang berhubungan dengan system budaya adalah sering terjadi juga pada masyarakat di perkotaan yang mempunyai gaya hidup budaya dengan tingkat kesibukan 
yang tinggi karena alasan pekerjaan. Contohnya : pada ibu-ibu di daerah perkotaan yang kurang dan tidak sering menyusui bayinya dengan Air Susu Ibu (ASI) setelah melahirkan tetapi hanya diberikan formula susu bayi instant. Padahal kita tahu bahwa ASI sangat penting untuk pertumbuhan dan perkembangan fisik bayi.

Selanjutnya gaya hidup mereka berasal dari golongan ekonomi atas (masyarakat elite kota), dalam hal makanan sering mengkonsumsi makanan yang berasal dari produk luar negeri atau makanan instant lainnya karena soal "gengsi". Sedangkan makanan local kita hanya dikonsumsi oleh mereka yang berasal dari golongan ekonomi menengah ke bawah karena ada anggapan bahwa makanan dari luar negeri kaya akan nilai gizi protein dan makanan instant lebih praktis dikonsumsi sedangkan makanan local kita nilai gizinya lebih kepada karbohidrat. Sehubungan dengan soal gengsi maka ada kebiasaan masyarakat di Timor jika ada kunjungan tamu ke rumahnya maka tamu tersebut selalu di hidangkan dengan makanan yang berasal dari beras walaupun kesehariannya mereka selalu mengonsumsi jagung, ubi kayu/singkong dan makanan local lainnya sehingga beras atau nasi telah dinggap sebagai suatu citra bahan makanan yang mempunyai nilai "prestise" yang tinggi.

\section{Masalah Budaya Makanan Terhadap Gizi}

Adanya kebiasaan dan system sosial masyarakat terhadap makanan seperti pola makan, tabu atau pantangan, gaya hidup, gengsi, dalam mengonsumsi jenis bahan makanan tertentu, ataupun prestise dari bahan makanan tersebut yang sering terjadi di kalangan masyarakat apabila keadaan tersebut berlangsung lama dan mereka juga belum memahami secara baik tentang pentingnya factor gizi dalam mengonsumsi makanan maka tidak mungkin dapat berakibat timbulnya masalah gizi kurang. Gizi salah (malnutrition) dapat didefinisikan sebagai keadaan sakit atau penyakit yang disebabkan kekurangan relative atau mutlak dan kelebihan satu atau lebih zat-zat makanan esensial yang berguna dalam tubuh manusia. Menurut bentuknya, gizi salah diklasifikasikan oleh (Supariasa et al., 2002) sebagai berikut :

1. Gizi kurang (Undernutrition), kondisi ini sebagai akibat dari konsumsi makanan yang tidak memadai jumlahnya pada kurun waktu cukup lama. Contoh : Kekurangan Energi Protein (KEP) dapat menyebabkan penyakit marasmus dan kwashiorkor.

2. Gizi lebih (Overnutrition), keadaan ini diakibatkan oleh konsumsi makanan yang berlebihn untuk jangka waktu yang cukup lama sebagai contoh : kegemukan.

3. Kurang gizi spesifik (Spesific Deficiency): keadaan ini disebabkan oleh kekurangan relative atau mutlak pada zat-zat makanan tertentu. Contohnya : kekurangan vitamin A yang dapat menyebabkan penyakit Xeropthalmia dan Gangguan Akibat Kekurangan Iodium (GAKI) yang dapat menyebabkan penyakit gondok.

4. Gizi tak seimbang (Inbalance); kondisi yang merupakan akibat dari tidak seimbangnya jumlah antara zatzat makanan esensial, dengan atau tanpa kekurangan zat makanan tertentu. Contoh : gangguan keseimbangan tubuh, sering loyo, dan lain-lain. (Banudi,SST, M.Kes \& Imanuddin,SP, M.Kes, 2017)

Adapun kekurangan gizi yang menyebabkan timbulnya penyakit stunting, terutama pada balita Menurut WHO, 
Indonesia termasuk ke dalam Negara ketiga dengan prevalensi tertinggi di regional Asia Tenggara / South-East Asia Regional (SEAR). Rata-rata prevalensi balita stunting di Indonesia tahun 2005-2017 adalah 36,4\%, sehingga persentase balita pendek di Indonesia masih tinggi. Menurut Riskesdas tahun 2018, provinsi Sulawesi Selatan masih berada di angka 35,4\%, dengan Kabupaten Enrekang tertinggi ke-5 dengan persentase 42\%. Data PSG tahun 2018 menunjukkan bahwa Kecamatan yang memiliki prevalensi stunting tertinggi yaitu Kecamatan Baraka sebesar 45,1\%. Menurut MCA-Indonesia (2015), stunting adalah masalah kurang gizi kronis yang disebabkan oleh asupan gizi yang kurang dalam waktu cukup lama akibat pemberian makanan yang tidak sesuai dengan kebutuhan gizi. Stunting terjadi mulai janin masih dalam kandungan. Stunting merupakan salah satu masalah gizi yang berdampak buruk terhadap kualitas hidup anak dalam mencapai titik tumbuh kembang yang optimal sesuai potensi genetiknya. Stunting dapat menghambat proses tumbuh kembang pada balita. Nutrisi adalah bagian penting dari kehidupan manusia. (Ibrahim dkk., 2021) Perbedaan budaya dan tingkat ekonomi berdampak pada perubahan kebiasaaan makan keluarga. Tingkat ekonomi yang baik membuat kelurga memiliki kesempatan yang lebih besar untuk memenuhi kehidupan nutrisi. Perbedaan budaya berdampak pada perubahan bahan, cara pengolahan, dan penyajian makanan. Tujuan utama pembangunan nasional adalah peningkatan kualitas Sumber Daya Manusia (SDM) yang dilakukan secara berkelanjutan. Salah satu factor penentu utama kualitas sumber daya manusia adalah gizi. Krisis ekonomi di Indonesia pada pertengahan 1997 telah berpengaruh negative terhadap kondisi perekonomian secara menyeluruh, khususnya terhadap kesejahteraan penduduk. Kondisi ini menyebabkan sebagian masyarakat tidak mampu mengakses pangan dan pada akhirnya berpengaruh terhadap keadaan gizi, terutama balita, serta ibu hamil dan ibu menyusui. (Muhith \& Wulandari, 2014)

\section{Faktor Yang Mempengaruhi Gizi}

Kualitas gizi di Indonesia sangat memperihatinkan. Gizi merupakan bagian penting dari kehidupan manusia yang tak dapat dilepaskan dari factor sosial budaya, serta lingkungan di mana masyarakat bertempat tinggal. Kebudayaan berpengaruh pada pola makan dan gizi masyarakat. Diketahui bahwa balita di Indonesia paling banyak mengalami gizi buruk dan gizi kurang. Factor yang mempengaruhi status gizi balita antara lain, kurangnya persediaan pangan dan kurang baiknya kualitas lingkungan. Adapun factor lain yang mempengaruhi adalah kondisi ekonomi dan budaya keluarga, tingkat pendidikan, dan pekerjaan.

Indonesia memiliki keanekaragaman budaya dengan latar belakang suku dan tata kehidupan sosial budaya yang berbeda. Perbedaan budaya berdampak pada perbedaan pemiloihan bahan, cara pengolahan, dan penyajian makanan. Para ahli sosiologi dan ahli gizi menyatakan bahwa factor budaya sangat berperan terhadap proses terjadinya kebiasaan makanan itu sendiri, sehingga tidak jarang menimbulkan berbagai masalah gizi apabila tidak diperhatikan baik. Masalah gizi pada balita akan berdampak serius terhadap kualitas generasi mendatang.

Solusi Dari Masalah Budaya Dan

Makanan Serta Gizi Yang Berkaitan Dengan Gizi Dan Kesehatan

Masalah budaya dan makanan kita ketahui dapat menyebabkan masalah gizi 
yang berdampak pada kesehatan tubuh manusia, sehingga perlu secara cermat untuk memberdayakan masyarakat local dengan kearifan dan kecerdasan local (local wisdom and local genius) disamping terus melaksankan penyuluhan gizi sebagai alternative mengtasi masalah budaya dan makanan.

Pendekatan yang paling utama adalah melalui perbaikan struktur sosial masyarakat tentang pandangan mereka terhadap bahan makanan walaupun local tetapi kaya akan nilai gizi. Langkah-langkah yang ditempuh seperti :

1. Perbaikan gizi keluarga dengan melakukan lomba menyiapkan hidangan makanan non beras (kasus budaya Timor).

2. Perbaikan budaya masyarakat dengan pengaruh utama gender terutama di tingkat keluarga.

3. Memperluas areal pertanian dengan menanam berbagai komoditi yang mempunyai nilai gizi yang tinggi sebagai bahan pangan/makanan seperti kedelai (kasus budaya Jawa).

4. Pemberian makanan tambahan yang bernilai gizi baik bagi anak-anak, balita, dan orang lanjut usia.

5. Penyuluhan gizi terpadu dan konsultasi gizi bagi masyarakat.

6. Melakukan pengkajian/penelitian dan riset untuk melihat pengaruh budaya terhadap makanan itu sendiri dengan berbagai implikasi yang terkait di dalamnya.

Upaya penanggulangan masalah gizi telah dilakukan pemerintah melalui pemberdayaan keluarga untuk menjaga ketahanan pangan di tingkat rumah tangga, peningkatan upaya pelayanan gizi terpadu, dan pengembangan system rujukan dari tingkat Pos Pelayanan Terpadu (Posyandu), puskesmas, rumah sakit, peningkatan komunikasi informasi dan edukasi di bidang pangan dan gizi masyarakat, serta intervensi langsung kepada sasaran melalui Pemberian Makanan Tambahan (PMT). Akan tetapi, hasilnya masih kurang signifikan terhadap penurunan masalah gizi di Indonesia. Oleh karean itu, perlu adanya strategi baru untuk mendukung upaya-upaya yang sudah dilakukan tersebut.

\section{Dimensi Etis Terhadap Budaya Makan}

Perilaku makan suatu masyarakat yang banyak didominasi oleh pola budayanya dari sudut etika khususnya etika makanan (food ethics). Kajian dari sisi etika membuka kemungkinan untuk dikembangkannya dengan aspek lain, seperti munculnya peran kapitalisme, teknologi, dan ilmu budaya.

Peran makanan dalam kebudayaan merupakan kegiatan ekspresif yang memperkuat kembali hubungan-hubungan dengan kehidupan sosial, sanksi-sanksi, agama, ekonomi, ilmu pengetahuan, teknologi dengan berbagai dampaknya. Dengan kata lain, kebiasaan makan atau pola makan tidak hanya sekedar megatasi tubuh manusia saja, melainkan dapat memainkan peranan penting dan mendasar terhadap ciri-ciri dan hakikat kebudayaan. (Meliono Budianto, 2004)

\section{Kesimpulan}

Dominasi kebudayaan manusia menjadi sangat berperan terutama dalam pola makanannya. Makanan terkategorisasi menjadi makanan yang boleh dan tidak boleh dimakan. Makanan yang dianggap nutriment belum tentu menjadi makanan yang boleh dimakan. Begitu sebaliknya, makanan yang boleh dan tidak boleh dimakan belum tentu memiliki nilai gizi yang memadai. Dengan demikian kategor makanan, pola makanan, dan system budaya 
Itu sangat berkaitan dengan budaya atau kepercayaaan yang ada di setiap daerah yang dimana dapat menimbulkan adanya kekurangan gizi pada balita, anak-anak, dan orang lanjut usia. Dan terkait dengan stunting, dari sebuah penelitian menyimpulkan bahwa tidak terdapat hubungan sosial budaya dengan kejadian stunting, dan juga tidak terdapat hubungan kepercayaan makanan dengan kejadian stunting, dimana hanya terdapat hubngan dukungan keluarga dengan kejadian stunting terutama pada balita.

Dimensi etis muncul ketika makanan berada di tangan konsumen, produsen, dan lingkungan manusia. Interaksi antar konsumen dengan produsen memnculkan aspek etis, yaitu hak dan kewajiban serta tanggungjawab moral. Kemudian adanya persepsi tentang konsep penyakit, kesehatan dan keragaman jenis ritual yang ada di setiap daerah terbentuk melalui proses sosialisasi secara turun temurun diyakini kebenarannya.

Disini perlu diperhatikan bahwa masyarakat bukan objek dari suatu perubahan tetapi masyarakat adalah subjek dari perubahan. (Zalfendi, 1999)

\section{Daftar Pustaka}

Banudi,SST, M.Kes, Dr. L., \&

Imanuddin,SP, M.Kes, I., SP, M.

Kes. (2017). SOSIOLOGI DAN

ANTROPOLOGI GIZI (1 ed.).

Forum Ilmiah Kesehatan

(FORIKES).
Ibrahim, I., Alam, S., Adha, A. S., Jayadi, Y.

I., \& Fadlan, M. (2021). Hubungan

Sosial Budaya Dengan Kejadian

Stunting pada Balita Usia 24-59

Bulan Di Desa Bone-Bone

Kecamatan Baraka Kabupaten

Enrekang Tahun 2020. 1(hubungan

sosial budaya dan stunting di

kabupaten enrekang), 16-26.

https://doi.org/10.24252/algizzai.vli1 .

19079

Meliono Budianto, V. I. (2004). Dimensi Etis

Terhadap Budaya Makan dan

Dampaknya pada Masyarakat.

8(Dimensi etis terhadap budaya

makan), 65-70.

https://doi.org/10.7454/mssh.v8i2.90

Muhith, A., \& Wulandari, L. (2014). Kondisi

Ekonomi dan Budaya Keluarga

dengan Status Gizi Balita. Jurnal

Ners, 9(Ekonomi dan status gizi), 1157.

Satrianegara, M. F., Juhannis, H., H.R. Lagu, Abd. M., Habibi, H., Sukfitrianty, S., \& Alam, S. (2021). Cultural 
traditional and special rituals

related to the health in Bugis Ethnics

Indonesia. 35 tambahan 1(Cultural

traditional and the health in bugis

ethnics indonesia), S56-S58.

https://doi.org/10.1016/j.gaceta.2020.1

2.016

Zalfendi, Z. (1999). Pengaruh sosial budaya

terhadap gizi masyarakat. FIK UNP, pengaruh sosial budaya terhadap

gizi, 1-10. 